\title{
Perspektive mjerenja utjecaja trećeg sektora u Hrvatskoj
}

DANIJEL BATURINA*

Studijski centar socijalnog rada

Pravni fakultet Sveučilišta u Zagrebu

Zagreb, Hrvatska
Prethodno priopćenje

UDK: 316.32:316.473(497.5)

doi: $10.3935 /$ rsp.v25i3.1504

Primljeno: listopad 2017.

Ovaj rad razmatra perspektive mjerenja utjecaja trećeg sektora u Hrvatskoj. Najprije se kratko konceptualizira treći sektor kao nov koncept u hrvatskom kontekstu, metodološki i drugi izazovi za njegovo mjerenje te dosadašnji razvoji pristupa mjerenja utjecaja u trećem sektoru. Rezultati kvalitativnog empirijskog istraživanja pokazuju da postoji konsenzus među sudionicima $u$ istraživanju o tome da je evidentna potreba za mjerenjem utjecaja sektora, kako bi se povećao legitimitet u javnosti i prema donatorima, ali i unaprijedilo vlastito djelovanje. Međutim, kapaciteti organizacija i provedbenih tijela su skromnog dosega. Konkretni alati i metode nisu na dnevnom redu organizacija te se može zaključiti da je područje mjerenja utjecaja nerazvijeno. Osim rezultata, rad daje i preporuke za napredovanje prakse mjerenje utjecaja s obzirom na stanje trećeg sektora i specifičnosti hrvatskog konteksta.

Ključne riječi: treći sektor, utjecaj, društveni utjecaj, mjerenje utjecaja.

\section{UVOD}

Potreba za utjecajima trećeg sektora $\mathrm{u}$ sadašnjem se trenutku pokazuje iznimno značajnom. Naglašeni demografski, trendovi tržišta rada te povećanje socijalnih tenzija uslijed pojave novih socijalnih rizika samo su neki od najvećih socijalnih izazova s kojima se Hrvatska i Europa moraju suočiti sada i u narednim desetljećima. Postaje sve jasnije da se vlade ne mogu same nositi sa svim problemima s kojima se društvo suočava. Treći sektor redovito ispunjava prostor između tržišta (prvi sektor) i državnih institucija (drugi sektor), promičući vrijednosti kao što su pravda i solidarnost, dok istovremeno donosi konkretan napredak u području socijalnog uključivanja i

${ }^{*}$ Danijel Baturina, Studijski centar socijalnog rada, Pravni fakultet Sveučilišta u Zagrebu / Department of Social Work, Faculty of Law, University of Zagreb, Nazorova 51, 10000 Zagreb, Hrvatska / Croatia, danijel.baturina@pravo.hr 
integracije (European Commission, 2012.). Kao takav, on postaje sve važniji element institucionalnog miksa u Europi.

Treći sektor kao cjelina, te svaka organizacija u njemu, treba znati kakav utjecaj ima na društvo u cjelini i na njegove specifične dijelove. Kao što je istaknuo Stiglitz (2009.) u svom izvješću, naš sustav mjerenja gospodarske aktivnosti mora biti proširen kako bi obuhvatio više dimenzija dobrobiti. Doprinos trećeg sektora na socijalnu dobrobit nije dovoljno analiziran niti s teoretskog stajališta niti empirijski (Bassi i sur., 2014.). Također ni njegovi ekonomski utjecaji uglavnom nisu dovoljno istraženi (Chaves i Monzon, 2012.).

Ovaj rad, temeljen na rezultatima empirijskog istraživanja, prikazuje kakva je trenutna perspektiva mjerenja utjecaja trećeg sektora Hrvatskoj. Najprije ćemo kratko konceptualizirati treći sektor kao izrazito dvojben koncept. Kako je mjerenje utjecaja trećeg sektora novo područje istraživanja u hrvatskom kontekstu, obrazložit ćemo zašto se sve više stavlja naglasak na mjerenje utjecaja, metodološke izazove za njegovo mjerenje te dosadašnje razvoje pristupa mjerenja utjecaja u trećem sektoru.

U drugom dijelu rada fokusirat ćemo se na prakse i perspektive mjerenja utjecaja u Hrvatskoj. Prikazat ćemo dosadašnje pokušaje mjerenja, te nakon opisa metodologije istraživanja, prikazati rezultate istraživanje u kojima ćemo sagledati kako sudionici istraživanja percipiraju mjerenje utjecaja, kakve metode se koriste i koliko je mjerenje utjecaja osviješteno kao koncept. Rezultate ćemo raspraviti u svijetlu tekućih trendova razvoja trećeg sektora u Hrvatskoj i barijera njegovom daljnjem razvoju. U zaključku ćemo sumirati ključne nalaze i dati preporuke za moguće unaprjeđenje prakse mjerenja utjecaja trećeg sektora $u$ Hrvatskoj.

\section{TREĆI SEKTOR - CRTICA O KONCEPTU}

Koncept trećeg sektora je osporavan, i ozbiljno je pitanje može li se uopće skup subjekata i aktivnosti koji držimo da mu pripadaju odrediti kao sektor (Dekker, 2004.; Evers i Laville, 2004.) Salamon (1995.) govori o njemu kao o »skrivenom potkontinentu od ogromne veličine i složenosti«, dok Zimmer i Evers govore o »svemiru koji čeka da se otkrije« (Zimmer i Evers, 2010.). Brandsen (2008.) navodi da je treći sektor donekle apstraktni pojam i »kišobran« termin koji se može specificirati u kontekstu specifičnih projekata.

Treći sektor ${ }^{1}$ se kao koncept veže uz ideju prema kojoj su osnovne društvene institucije država i tržište, stoga civilno društvo u tom slučaju čini treći sektor, razumijevajući tako sektor kao rezidualnu kategoriju za manifestacije koje ne pripadaju niti tržištu niti državi (Corry, 2010.) Treći sektor je obuhvatan pojam. Njega zasebno uvode Etzioni i Levitt početkom 1970-ih, polazeći od argumenta o neuspjehu tržišta i neuspjehu (rastuće) socijalne države u osiguranju socijalne zaštite (Lorentzen, 2010.). Etzioni treći sektor vidi kao alternativu državi i tržištu, moguće najvažniju alternativu koja neće zamijeniti druga dva sektora, nego nadopuniti i balansirati njihove važne uloge (Etzioni, 1973.: 315). Glavne prednosti trećeg sektora prepoznaju se u njegovom kombiniranju poduzetničke orijentacije i organizacijske učinkovitosti poslovnog sektora s orijentacijom prema

\footnotetext{
${ }^{1}$ Pojam trećeg sektora upućuje na tzv. sektorski model organizacije društva (Wuthnow, 1991.: 5) koji uz državu i tržište podrazumijeva različite institucije i organizacije koje su značajan dio društvenog života. Podrazumijeva se da treći, kao i ostali sektori, ima kapacitet doprinijeti ili postići različite društvene funkcije.
} 
javnom dobru, prisutnom u javnom sektoru (Etzioni, 1973.).

Različiti su i pristupi definiranju trećeg sektora. ${ }^{2}$ Primjerice, Enjolras (2015.) navodi »ontološki« pristup, koji razumije treći sektor kao određenu vrstu institucije (ili grupe aktera) sa specifičnim karakteristikama »trećeg sektora«. Treći sektor koncipira se kao hibridni oblik (Evers, 1995.: 160) raznih vrsta organizacija (tvrtki, javnog sektora, udruga) koje, djelujući kao hibridi, isprepliću različite resurse i povezuju različita područja, prije nego imaju jasnu crtu razgraničenja sektora $\mathrm{i}$ mapiranja njegove veličine.

Sektor je aktivan i razvija se u mnogim područjima ekonomije, zdravlja i skrbi, socijalnih usluga, kulture, okoliša, obrazovanja i zapošljavanja kroz različite subjekte koji se temelje na različitim pravnim statusima prema nacionalnom pravnom i kulturnom okviru. Kako postoji mnogo različitih pravnih statusa za vrste subjekata koji pripadaju neprofitnom sektoru, ne postoji opća teorija koja može objasniti granice i konkurentne prednosti sektora u cjelini (OECD, 2003.).

$\mathrm{U}$ potrazi za definicijom naslanjamo se na rad Third sector impact ${ }^{3}$ projekta (Salamon i Sokolowski, 2014.). Njihova definicija pokušava nadvladati dva teoretska pristupa koja su se proširila. Jedan koji naglašava neprofitni sektor, proizašao iz Johns Hopkins Comparative Nonprofit Sector Project (Salamon i Anheier 1997.;
Salamon i sur., 2004.) te drugi koji naglašava socijalnu ekonomiju i u zadnje vrijeme sve intenzivnije socijalno poduzetništvo (primjerice, Borzaga i Defourny, 2001.; Evers i Laville, 2004.; Defourny i Nyssens, 2010., 2016.).

Prema definiciji (Salamon i Sokolowski, 2014.), institucionalne komponente trećeg sektora moraju zadovoljiti kriterije da su: 1) organizacije - uključuju grupe ljudi, bilo da su registrirane ili ne, koji su u interakciji prema nekim međusobno prihvaćenim procedurama i slijede jednu ili više zajedničkih svrha kroz određeni (značajni) vremenski period; 2) privatne - institucionalno odvojene od države i s mogućnosti da prestanu djelovati vlastitom odlukom; 3) samo-upravljajuće - određuju svoju osnovnu misiju i svrhu koje su formulirane kroz interne procedure vladavine/imaju samostalnost u izboru vodstva/ određen stupanj financijske autonomije; 4) dobrovoljne uključuju ljude bez prisile ili prinude na temelju slobodnog izbora i 5) u potpunosti ili značajno ograničene u distribuciji dobiti - ili potpuno zabranjuju raspodjelu dobiti ili neka pravna ili ugovorna obveza od njih traži da ograniče ovu distribuciju. ${ }^{4}$

U ovoj definiciji organizacijskih oblika trećeg sektora prihvaćena su prva četiri kriterija definicije neprofitnog sektora John Hopkins projekta. Peti kriterij ograničenja raspodjele dobiti razrađen je kako bi naglasio aspekte ekonomske aktivnosti organizacija trećeg sektora koja postaje sve važnija,

2 Također, različite discipline imaju različit fokus na treći sektor. Primjerice, ekonomisti su analizirali zašto privatne organizacije rade za javnu svrhu. Sociolozi percipiraju ove organizacije kao pokretače participacije, socijalne integracije i društvene stratifikacije (Zimmer i Freise, 2006.). Politolozi su zainteresirani za funkciju pružanja usluga od organizacija trećeg sektora, percipirajući ih kao aktere javno privatnog partnerstva, u domeni socijalne države (Janei i Kuti, 2008.).

${ }^{3}$ EU Seventh Framework Programme project Third Sector Impact 2014-2017 (grant agreement 613034).

${ }^{4}$ U barem četiri od sljedećih pet načina: • pridržavajući se eksplicitne socijalne misije koja ih ograničava u maksimizaciji dobiti; • ograničavanjem raspodjele dobiti na 50 posto; • pridržavanjem capital lock principa za imovinu koju posjeduju; • zapošljavanjem ili pružanjem usluga značajnom udjelu (npr. barem 30 posto) osoba s posebnim potrebama; • pridržavajući se zabrane raspodjele dobiti na temelju uloženog kapitala ili plaćenih naknada i članarina. 
posebice u dijelovima socijalnih poduzeća i organizacija socijalne ekonomije. Ovakav pristup, naravno, ima svoja ograničenja ${ }^{5}$. No, ova definicija je konsenzusni pokušaj omeđivanja granica sektora, koja ima svoju praktičnu i istraživačku svrhu te ćemo je koristiti kao operativnu ${ }^{6} \mathrm{u}$ ovom radu.

\section{MJERENJE UTJECAJA TREĆEG SEKTORA: DOSADAŠNJI RAZVOJ I TRENDOVI}

\section{Oblikovanje perspektive mjerenja utjecaja}

Koncepcija prema mjerenju utjecaja razvijala se u trećem sektoru (ali i van njega) zadnjih desetljeća. Participativna procjena utjecaja bila je brzo rastuća u 1980-ima (World Bank, 2006.). Ebrahim i Rangan (2010.) razvoj koncepcije gledaju kroz dva pravca. Prvi, »odgovornosti« koji se javlja 1990-ih, sa zahtjevima donatora, i drugih dionika prema neprofitnim organizacijama da budu više transparentne u prikupljanju i trošenju sredstava. Novija manifestacija tog diskursa usmjerena je na utjecaj ili pokazivanje rezultata u rješavanju složenih društvenih problema. Važan pokretač obnovljenog interesa za društveni utjecaj može biti pojava novih tzv. venture filantropa od 1990-ih, od kojih su vidjeli filantropiju kao oblik socijalnog ulaganja koje kao i financijsko ulaganje treba izvijestiti o svom povratu 7 (Zappalà i Lyons, 2009.). Taj oblik gledanja na "povrat « aktivnosti trećeg sektora danas se manifestira kroz paradigmu obveznica društvenog utjecaja (McHug i sur., 2013.) ${ }^{8}$.

Mjerenje i ocjenjivanje organizacijskih performansi i društvenog utjecaja organizacija trećeg sektora pretvorilo se u jedno od najpopularnijih pitanja u stručnim i akademskim forumima tijekom posljednjeg desetljeća, zajedno s predmetima transparentnosti i odgovornosti (Rey Garcia, 2008.). Međutim, utjecaj nije nužno nova pojava u trećem sektoru. Harlock (2013.) drži da mnoge organizacije trećeg sektora odavno raspravljaju svoju učinkovitost u rješavanju društvenih problema, podršci ranjivim ljudima i promicanju određenih svrha kako bi prikupile sredstva ili privukle volontere. No, brojni su izazovi napretku prakse i metodologije mjerenja utjecaja kako organizacija, tako i sektora.

Jedan od njih je terminološke prirode. Različiti pojmovi, kao što su utjecaj, ishod, efekt, društveni/socijalni povrat, društvena vrijednost i performans još se uvijek jasno ne razlikuju u korištenju te i sam pojam utjecaja ima mnogo različitih definicija (Maas, 2008.). Pod utjecajem podrazumijevamo dio ukupnog ishoda koji se dogodio kao rezultat aktivnosti organizacije, iznad i izvan onoga što bi se dogodilo svejedno (Maas i Liket, 2011.; European Commission, OECD, 2015.). To je sveukupna i dugotrajna razlika koja se postiže kroz programe intervencije i usluge (Harlock, 2013.).

Postoje i različite vrste utjecaja. U kontekstu trećeg sektora, društveni utjecaj se općenito referira kao šire vanjske prednosti

\footnotetext{
${ }^{5}$ Koje više autora konstruktivno komentira u posebnom dijelu časopisa Voluntas 27 (3), 2016., koji je posvećen navedenoj definiciji i komentarima na nju.

${ }^{6}$ Značajno više o konceptualizaciji trećeg sektora u Baturina, 2016.

7 Trenutni interes i entuzijazam za mjerenje socijalnih programa ili utjecaj nije nov. Autori ga drže sličnim evaluaciji socijalnih programa koja je bila popularna od sredine 1970-ih i u 1980-im godinama. Može se reći da se to isto usmjerenje manifestira sada u širem i rigoroznijem obliku, onome demonstriranja i mjerenja utjecaja.

${ }^{8}$ Osim toga, kako dokazi o učinkovitosti alociranja resursa dobivaju sve veću važnost, utjecaj se sagledavao u evaluacijskim istraživanjima koja razlikuju teorije procjene programa, procjene procesa programa i mjerenje ishoda/ utjecaja programa (Schober i sur., 2012., u: Simsa i sur., 2014.).
} 
za društvo, gospodarstvo i/ ili okoliš ${ }^{9}$ koje organizacija može stvoriti preko svojih aktivnosti, umjesto da se fokusiraju isključivo na izravne rezultate za pojedince ili privatne korisnike ili dionike (Wainwright, 2002.; Arvidson i sur., 2013., u: Harlock, 2013.). Društveni utjecaj je u suprotnosti s ekonomskim utjecajem sektora, koji se fokusira uže na utjecaj sektora u gospodarstvu i/ili na pojedine ekonomske sustave, a oslanja se na tržišne teorije i mjerne alate. U razmatranju kategorija utjecaja Olsen i Galimidi (2008.) naglašavaju ekonomsku dimenziju koja uključuje financijski utjecaj na druge osobe koji nisu vlasnici ili investitori. Može uključivati financijske rezultate poslovanja, kao što su promjene u dohotku ili financijska stabilnost zaposlenika ili članova zajednice ili utjecaj na javne prihode ili rashode.

Mjerenje utjecaja razvija se već nekoliko desetljeća s jačanjem naglaska prema povratu i učinkovitosti organizacija koje djeluju u sektoru. Veći naglasak stavlja se na društveni utjecaj, iako još uvijek postoje određene terminološke zabune čak i oko samog pojma utjecaja.

\section{Metodološki izazovi mjerenja utjecaja trećeg sektora}

Mjerenje utjecaja trećeg sektora je velik izazov zbog različitih razloga od kojih je dobar dio metodološke prirode. Prije svega, sektor je heterogen i raznolik u vezi svojih uloga i funkcija. Različite organizacije mogu imati vrlo različite pristupe i razloge za poduzimanje aktivnosti mjerenja utjecaja, ovisno o njihovom organizacijskom cilju (Harlock, 2013.). Organizacije trećeg sektora kao i sam sektor imaju više dionika. Svi oni mogu imati različita očekivanja i percepcije uloge i postignuća organizacija trećeg sektora.

Jedno od ključnih pitanja je pripisivanje kauzalnosti akcijama trećeg sektora smatrajući da oni proizvode određeni utjecaj. Pitanje je koliko je dobro shvaćen odnos između uzroka i učinka određene intervencije (Bassi i Vincenti, 2015.). Vjerojatno će više čimbenika i aktera djelovati na utjecaj. Konstruiranje protučinjenica bitno je za analizu utjecaja, međutim ono je posebice kompleksno kada su ciljevi organizacije višestruki kao što je to često slučaj s organizacijama trećeg sektora i stoga ih je teško analizirati na agregatnoj razini (DiMaggio, 2001.). Dodatno, čak i definicije nezavisnih varijabli poput volontiranja, socijalnih poduzeća ili pak trećeg sektora uvelike se razlikuju $^{10}$ (Simsa i sur., 2014.). Jedan od najvećih problema je pripisivanje (atribucija) utjecaja na makro- i mikrorazini u trećem sektoru. Osim toga, većina istraživanja ne bavi se problemom smjera kauzalnosti.

Dodatni izazov je mjerenje tzv. »mrtvog tereta«. Ovaj pojam označava one posljedice koje bi se dogodile u svakom slučaju bez obzira na djelovanje organizacije. Kako eksperimentalni dizajn u većini slučajeva nije moguć, analitičari moraju raditi oko problema razmatrajući na neki način »mrtvi teret« koji se pojavljuje u obliku slučajnih utjecaja, većeg društvenog razvoja, djelovanja samih korisnika, doprinosa intervencija drugih organizacija trećeg sektora ili državnih institucija koje rade paralelno svojim raspoloživim kapacitetima (Maier i sur., 2014.; Simsa i sur., 2014.). Postavlja se pitanje i oportunitetnih

\footnotetext{
${ }^{9}$ Utjecaji koji imaju veze sa statusom prirodnih resursa i ekosustava će, iako važni, biti samo posredno tematizirani u ovom radu i dijelom će ih se uklopiti u širu perspektivu društvenih utjecaja.

10 Kao rezultat, ne postoji sustavna korespondencija između mikroindikatora i makropokazatelja što otežava sustavan pokušaj da se razvije cjelovit niz pokazatelja te je malo mogućnosti komparativne analize (Simsa i sur., 2014.).
} 
troškova. Zahtjevno je i gotovo nemoguće pitanje razlučiti bi li isti resursi, uloženi u neki od drugih sektora, proizveli značajnije utjecaje.

Što se tiče temporalne dimenzije, točan utjecaj određenog djelovanja često se javlja kao privremeno (vremenski) odgođen i ne može se uopće ili se rijetko može sveobuhvatno pripisati određenoj akciji ili organizaciji. To je još i teže kada je utjecaj namijenjen ne za osobu, nego za sustavnu mezo- ili makrorazinu (Achleitner i sur., 2009.).

Kao što smo prikazali, metodološke prepreke mjerenju utjecaja su brojne i stoga je iznimno teško povezati utjecaje s djelovanjem sektora ili organizacija u njemu. To je utjecalo i na oblikovanje pristupa prema mjerenju utjecaja.

\section{Pristupi mjerenju utjecaja - kratki osvrt}

Postoji obilje pristupa mjerenju i procjeni utjecaja u trećem sektoru. No, većina postojećih tehnika jednostavno mjeri specifične ishode programa, prije nego hvata dugoročne ili sustavne društvene utjecaje (Edwards i sur., 2012.). Logika analize kombinirane (ili pomiješane) ${ }^{11}$ vrijednosti ukazuje na to da, kao prvo, organizacije trećeg sektora stvaraju i financijsku i društvenu vrijednost, te da su te vrste stvaranja vrijednosti suštinski povezane ${ }^{12}$ (Manetti, 2014.). Većina alata i metoda bar dijelom odražava tu logiku. Polazna točka je i tzv. trostruka bilanca (Elkington, 2004.), koja, osim financijskog, pruža mjerenje društvenog i ekološkog utjecaja. Ona dobiva sve više pažnje te se razvijaju integriraniji i standardiziraniji pristupi.

Maas i Liket (2011.) navode čak trideset različitih metoda mjerenja ${ }^{13}$ od kojih su neke više zastupljene u praksi. Dajući pregled pokušaja mjerenja društvenog utjecaja, Dufour (2015.) navodi čak više od osamdeset mogućih metoda, što još uvijek nije iscrpna lista (više u Baturina, 2016.). Metode za mjerenje utjecaja razlikuju se u više aspekata poput svrhe, vremenskog okvira, orijentacije, duljine vremenskog okvira, perspektive i pristupa (Maas i Liket, 2011.). Može se dijelom otkriti sklonost kretanja od standardnih alata izvedbe kao što je balansirana izvještajna tablica (Kaplan, 2001.) prema (kvazieksperimentalnim) procjenama ishoda i utjecaja, koje uključuju fokus na utjecaje povezane s misijom, koja je ključna za postojanje organizacija trećeg sektora (Simsa i sur., 2014.).

Europska komisija (2013.) navodi da je teško zagovarati jednu metodu. Isto tako, umjesto razvijanja novih metoda, Komisija predlaže da se gradi svijest o najčešće korištenima. Preporučuje se da se metode razvijaju i pilotiraju, pomno prate i, ako je potrebno, revidiraju. Mjerenje pritom treba tražiti ravnotežu između kvalitativnih i kvantitativnih podataka ${ }^{14}$, shvaćajući da je »priča« središnja za mjerenje uspjeha. Potrebno je tragati za dokazima visoke kvalitete koji si robusni i prikladni te pomažu identificirati utjecaj, a zatim nastavljati generirati odgovarajuće vrste dokaza kako

11 Eng. blended.

${ }^{12}$ Umjesto da su u opoziciji kao nul sum jednadžba, tj. da za generiranje više društvene vrijednosti organizacija mora žrtvovati svoje financijsko poslovanje

${ }^{13} \mathrm{Uz}$ to, primjerice, Krlev i sur. (2014.) sagledali su pristupe mjerenju utjecaja bliske socijalnim inovacijama. Ocijenili su više od 45 pristupa. Mjerenja s naglaskom na treći sektor i njegov doprinos inovacijama su rijetka među postojećim metodologijama koje su oni proučavali.

${ }^{14}$ Promičući razne oblike mješovitih metodologija mjerenja, promičemo i metodološku raspravu daleko od norme razvojnih istraživanja u kojoj kvalitativno istraživanje igra »drugu violinu« konvencionalnom empirijskom istraživanju (Gabarino i Holland, 2009.). 
bi se osiguralo njegovo praćenje (NESTA, 2013.).

Brojne metode za mjerenje utjecaja razvile su se pokušavajući zahvatiti i društveni i ekonomski utjecaj organizacija trećeg sektora. Međutim, ne postoji konsenzus oko najprikladnijih, te se očekuju njihov daljnji razvoj.

\section{Zašto mjeriti utjecaj trećeg sektora?}

Na kraju se postavlja pitanje zašto uopće mjerimo utjecaj trećeg sektora i kakva je korist od toga. Smjernice o utjecaju iz sektora naglašavaju da je ocjenjivanje i mjerenje utjecaja od vitalnog značaja za organizacije trećeg sektora kako bismo razumjeli učinke svojih intervencija i usluga za svoje korisnike (Harlock, 2013.). Bassi i Vicenti (2015.) zaključuju da bi mjerenje utjecaja moglo biti vođeno uglavnom ekonomskim razlozima (zabrinutost financijera $\mathrm{i}$ donatora); političkim razlozima (povećanje ugleda organizacije i legitimacija ili slika i vidljivost u lokalnoj zajednici); društvenim opravdanjem (da procijene kvalitetu odnosa, partnerstva, mreža, kojih je organizacija član; i razine povjerenja od strane drugih organizacija) ili etičkim motivima. Mjerenje društvenog utjecaja može pomoći postaviti realne ciljeve, u praćenju i poboljšanju performansi, prioritiziranju odluka i kompetitivnijem pristupu (European Commission, OECD, 2015.). Mjerenje u konačnici stremi pokazati jesu li organizacije trećeg sektora učinkoviti i održivi načini odgovora na društvene potrebe, ali isto tako, promiče politike temeljene na dokazima. Utvrđivanjem utjecaja: (1) mogu biti donesene bolje odluke o tome koje intervencije treba nastaviti i kako se trebaju nastaviti i (2) mjere ublažavanja mogu se provesti kako bi se smanjila šteta i maksimizirale koristi od određene planirane intervencije ili srodne djelatnosti (Vanclay, 2003.).

Kvaliteta, jasnoća i transparentnost može jednako biti od vrijednosti za korisnike organizacije. Za mjerenje utjecaja također se tvrdi da pomaže organizacijama privući volontere, poboljšati motivaciju osoblja te osigurati sredstva. Mjerenje utjecaja i njegovi proizvodi pružaju moćan alat za komunikaciju što organizacija ili treći sektor u cjelini radi. Ebrahim i Rangan (2014.) navode kako će omogućiti oboje donatorima i primateljima donacije da naprave poboljšanja u svom radu. Ali, ipak, i većina organizacija vjeruje da mjerenje utjecaja čini organizaciju učinkovitijom. Prijelaz na mjerenje društvenog utjecaja može pomoći organizaciji graditi na onome što radi dobro i učiti od izazova s kojima je suočena, uočiti što spada u dobru praksu i omogućiti da organizacija uči i napreduje (Rinaldo, 2010.). Usredotočivanje napora na ono što zaista čini razliku pomaže organizaciji da planira strateški i alocira resurse učinkovitije (Eurodiaconia, 2010.).

Kao što smo ukazali, motivacije za mjerenje utjecaja mogu biti različite, no uglavnom spadaju pod kategorije mjerenja da bi se pokazalo što organizacije doprinose ili kako bi se poboljšao njihov rad.

\section{MJERENJE UTJECAJA TREĆEG SEKTORA U HRVATSKOJ - DOSADAŠNJI PRISTUPI I SPOZNAJE}

Kada govorimo utjecaju trećeg sektora i posebice o pokušaju njegovog mjerenja, u hrvatskom kontekstu ne nalazimo mnogo relevantnih istraživanja. ${ }^{15} \mathrm{Od}$ pokušaja mjerenja utjecaja (prvenstveno u zadnjem desetljeću) nalazimo nekoliko zanimljivih pokušaja u smislu pristupa, dimenzija i ra-

\footnotetext{
${ }^{15}$ No, sukladno temi, ovdje se nećemo osvrtati toliko na utjecaj (više tematizirano u Baturina, 2016.), nego na načine na koje se pokušavao mjeriti.
} 
zina koji se više odnose na civilno društvo nego ne treći sektor kao takav. Dobar dio njih bio je usmjeren na partikularne dimenzije ili tek posredno sagledavao utjecaj kao što će biti pojašnjeno u nastavku.

Škrabalo u akcijskom istraživanju analizira organizacije osnovane s ciljem izgradnje mira (Škrabalo, 2006.) sagledavajući dimenzije utjecaja povezane s razvojem zajednice. Istraživanje utjecaja volontera u izgradnji mira (Jindra, i sur., 2007.) sagledavalo je utjecaj volonterskog rada u zajednici na razvoj zajednice, povećanje motivacije za volonterski rad te smanjenje stereotipa. Ovo je jedno od rijetkih koje je koristilo eksperimentalni dizajn, no s druge strane, bilo je geografski ograničeno i ispitivalo jako specifičan utjecaj.

Istraživački projekt CIVICUS Indeks civilnog društva proveden je i u Hrvatskoj, $i$ to u svim istraživačkim fazama ${ }^{16}$ (3 faze: 2001., 2003.-2005. te 2008.-2010. godine). Jedna od dimenzija koja se mjerila bio je i (percipirani) utjecaj civilnog društva. Metodologija indeksa temelji se na triangulaciji istraživačkih metoda $\mathrm{i}$ instrumenata. Osim u upitniku za organizacije, percepcija utjecaja civilnog društva ispitivana je $\mathrm{i}$ upitnikom za vanjske dionike, te regionalnim konzultacijama.

Nekoliko je dodatnih pokušaja longitudinalnih istraživanja koje se manjim dijelom usmjeravaju na utjecaj. Istraživanje Vidljivost $i$ javna percepcija udruga $u$ Hrvatskoj 2012., provedeno telefonskom anketom na nacionalnom reprezentativnom uzorku građana Republike Hrvatske daje neke zaključke o percepciji utjecaja udruga. Franc i sur. (2012.) ispitivali su koliko građani poznaju udruge, kao pojam, njihov rad i percepciju zadovoljstva njihovim radom (utjecajem) u određenim područjima. ${ }^{17}$ Istraživanje o procjeni stanja razvoja civilnog društva provedeno je 2011. godine, kao nastavak istraživanja iz i 2007. i 2009. godine (NZRCD, 2009.; NZRCD, 2011.). U njemu se dijelom istraživala percepcija utjecaja udruga na tijela vlasti ${ }^{18}$.

USAID Indeks održivosti organizacija civilnog društva, kroz izvještaje Indeks održivosti organizacija civilnog društva u Hrvatskoj ${ }^{19}$ posredno tematizira utjecaj od 1997. godine. Zadnjih pet godina istraživanje provodi organizacija CERANEO. Metodologija se sastoji od procesa individualnog ocjenjivanja različitih dimenzija održivosti civilnog društva od strane odabranih ključnih dionika u sektoru, o kojem se zatim raspravlja tijekom panela OCD stručnjaka te konsenzusom donose konačni rezultati za svaki od pokazatelja i dimenzija (CERANEO, 2017.).

Kao svojevrsna evaluacija provedeno je istraživanje Društveni $i$ gospodarski učinci podrški Nacionalne zaklade za razvoj civilnoga društva (Brajdić Vuković i sur., 2014.). Metodologija se oslanjala na uspoređivanje organizacija koje su primale podršku i onih koje nisu, anketu prema građanima o poznavanju organizacija te bazične izračune prema jednostavnim pokazateljima. $^{20}$

\footnotetext{
${ }^{16}$ Rezultati istraživanja za sve tri faze opsežno su predstavljeni u sljedećim publikacijama: Bežovan, 2005.; Bežovan i Zrinščak, 2007.; Bežovan i Matančević, 2011.

${ }^{17}$ Ono je nastavak istog istraživanja koje je napravljeno 2006. i 2007. godine.

${ }^{18}$ Istraživanje 2011. godine provedeno je metodom osobnog intervjua s vodećim osobama udruga, državnog proračuna ili dijela prihoda igara na sreću s realiziranim uzorkom od 651 udruge.

${ }^{19}$ Dimenzije indeksa su: pravno okruženje, organizacijski kapaciteti, financijska održivost, zagovaranje, pružanje usluga, infrastruktura te javna slika (imidž). To je nastavak prije poduzetnih Indeksa, koji se i dalje nastavljaju. Indeks je razvila Američka agencija za međunarodni razvoj u suradnji s lokalnim organizacijama iz zemalja u kojima se Indeks primjenjuje

${ }^{20}$ Pokušavali su se također izračunati društveno-gospodarski učinci projekata i inicijativa u području demokratizacije i razvoja društva.
} 
Što se tiče policy usmjerenih analiza, pri procesu priključivanja EU organizacije civilnog društva se dijelom istraživale posrednost ili neposrednost utjecaja civilnog društva na programiranje na nacionalnoj razini (Sumpor i Đokić, 2013.). Osim toga, autori Petak i Vidačak, (2015.), temeljeno na sekundarnoj analizi, sagledavaju gradnju kapaciteta i utjecaj na politike. Utjecaj trećeg sektora u dimenziji socijalnih inovacija aktualizirao se kroz nedavna istraživanja (Bežovan i sur., 2014.a, 2014.b, 2016.a) gdje se utjecaj trećeg sektora istraživao intervjuima s ključnim dionicima te studijama slučaja.

Dosadašnja istraživačka praksa daje ograničene uvide u utjecaj trećeg sektora. Korištene su raznolike metodologije za procjenjivanje uglavnom parcijalnih dijelova sektora.

$\mathrm{Na}$ razini organizacija teško možemo utvrditi postojanje prakse mjerenja jer ne postoji mnogo istraživanja. Tek nekoliko organizacija je primijećeno da pokušava koristiti SROI ${ }^{21}$ te izračunavati efekt lokalne multiplikacije, ${ }^{22}$ no može se utvrditi da su organizacije do sada imale praksu praćenja logike projektnih izvještaja. Kao dio obrazaca prijava projekta za različita provedbena tijela zadnjih se godina pojavio pristup logičke matrice, no ona ima veću važnost pri postupku prijave projekata nego pri praćenju rezultata i izvještavanju.

Organizacija ACT provela je istraživanje mjerenja organizacija civilnog društva, donatora i donosioca odluka ${ }^{23}$ (Glavina Petričević i Magdalenić, 2014.). Rezultati istraživanja pokazuju da gotovo $90 \%$ udru- ga iz uzorka i više od polovice donatora mjerenje utjecaja smatraju važnim, a čak 92\% donatora i kreatora politika smatra da organizacije stvaraju društveni utjecaj. Međutim, manje od pola donatora zahtijeva da organizacije mjere društveni utjecaj te ga manje od pola organizacija zaista i mjeri. Kada se mjeri utjecaj, većinom je to na području socijalnog uključivanja te organizacije koriste kombinaciju više metoda ili vlastite metode. Kao razloge za neprovođenje mjerenja utjecaja, u najvećoj mjeri organizacije navode nedostatak educiranosti (Glavina Petričević i Magdalenić, 2014.). ${ }^{24}$

Osim CIVICUS Indeksom civilnog društva koji je nešto detaljnije istraživao utjecaj civilnog društva, no od kojeg je prošlo više godina, ostala istraživanja posredno sagledavaju utjecaj ili ga pak ograničavaju na pojedine aspekte. Rezultati prethodnih istraživanja u Hrvatskoj ukazuju i na nisku razinu prisutnosti mjerenja utjecaja u sektoru. Oni su oblikovali istraživački pristup kojim se htjelo saznati više o motivaciji, potrebi i kapacitetima trećeg sektora, kao šireg, za mjerenje utjecaja.

\section{METODOLOGIJA ISTRAŽIVANJA}

Glavni cilj rada je istražiti kakva je trenutna perspektiva mjerenja utjecaja trećeg sektora u Hrvatskoj. Pri tome su glavna istraživačka pitanja naglašena nakon pregleda literature bila utvrditi mišljenja sudionika istraživanja o tome kakva je motivacija za mjerenjem utjecaja trećeg sektora, kakvi su kapaciteti različitih sudionika te

\footnotetext{
${ }^{21}$ Social return of Investment

${ }^{22}$ Što je rijetko objavljivano, pa je istraživač došao do tih podataka kroz osobne uvide u rad organizacija.

${ }^{23}$ U okviru sporazuma o suradnji na razvoju i pripremi uvođenja sustava mjerenja društvenog utjecaja organizacija civilnoga društva koji su potpisali s Nacionalnom zakladom za razvoj civilnoga društva. Rezultati su predstavljeni na konferenciji »Društveni utjecaj organizacija civilnoga društva u Republici Hrvatskoj« 25. rujna 2014. godine.

${ }^{24}$ No, mora se napomenuti da nemamo informacija o načinu uzorkovanja, tek podatak da je $15 \%$ organizacija ispunilo anketni upitnik (od 500 poslanih).
} 
kakav je stupanj razvijenosti i primjene metoda mjerenja utjecaja u Hrvatskoj?

Kako je utjecaj i njegovo mjerenje relativno neistražen fenomen u Hrvatskoj, istraživanje se temeljilo na kvalitativnom istraživačkom dizajnu. Kvalitativne metode su po svojoj prirodi »istražiteljske« i pogodne za istraživanje fenomena ili koncepata koji su novi i nedovoljno istraženi (Creswell, 2003.). Kvalitativni istraživački dizajn kao kontinuiran proces unutar kojeg je dopuštena određena fleksibilnost $u$ interakciji teorije i podataka (Ritchie i Lewis, 2003.) uključio je analizu policy dokumentacije i zakonskog okvira razvoja sektora te polustrukturirane intervjue s glavnim akterima sektora, sudionicima istraživanja. ${ }^{25}$ Takav pristup korišten je uslijed istraživanja trećeg sektora i mjerenja utjecaja kao novih tema, do sada skromno istraživanih u Hrvatskoj. ${ }^{26}$

Strategija uzorkovanja sudionika za potrebe intervjua temeljila se na namjernom uzorku sudionika prema kriteriju $»$ najboljeg informatora«. U uzorak je odabrano 16 sudionika. Oni su odabrani po kriteriju da imaju što šire uvide u utjecaj organizacija trećeg sektora, da rade i kontaktiraju sa širokim krugom organizacija i da su mnogi od njih kao provedbena tijela kontinuirano uključeni u evaluacije i praćenje većeg broja projekata i programa organizacija. Dakle, kriteriji su bili ekspertnost za temu i uključenost u temu. ${ }^{27}$

Strategija analize podataka je analiza putem nacrta (Milas, 2005.: 603), odnosno prema tematskom okviru mjerenja utjecaja trećeg sektora u Hrvatskoj. Strategija analize druge razine temeljila se na deduktivnoinduktivnom procesu polazeći od tematskog okvira koji je, slijedeći istraživačka pitanja, reflektirao definirane teme na koje je istraživač želio dobiti odgovor, međutim ostavljajući prostor za definiranje novih tema iz analizirane građe.

Pri analizi intervjua koristio se višestruki postupak otvorenog kodiranja u kojem je empirijska građa, nakon transkribiranja i pripreme za analizu, kodirana iterativno u dva odvojena navrata od strane istog

${ }^{25}$ Osim teme ovog rada, ispitivao se i utjecaj trećeg sektora za potrebe izrade doktorske disertacije Baturina, D. (2016). Utjecaj trećeg sektora na socio-ekonomski razvoj Republike Hrvatske. Zagreb: Pravni fakultet u Zagrebu u dimenzijama: dobrobit i kvaliteta života; socijalne inovacije; građanska zauzetost, osnaživanje, zagovaranje, izgradnja zajednica; ekonomski utjecaji te utjecaj na ljudske resurse. Ovaj rad predstavlja prikaz i dodatnu refleksiju na jedan dio rezultata istraživanja provedenih u okviru doktorske disertacije. Osim toga, u doktorskoj disertaciji su poduzete ekstenzivne studije slučaja šest organizacija trećeg sektora, no one nisu tematski u fokusu rada.

${ }^{26}$ Fleksibilnost je omogućila prilagodbu interakcije između istraživača i sudionika istraživanja, uzimajući u obzir da su treći sektor i mjerenje utjecaja nove teme u našem kontekstu. Stoga je bilo potrebno više prilagodljivosti u interakciji prema specifičnim sudionicima istraživanja, uzimajući u obzir ciljeve istraživanja, kao i njihov položaj i prethodna znanja i iskustva. Također, nove teme trećeg sektora i mjerenja utjecaja su sa sobom nosile konstantnu refleksiju između teorije $\mathrm{i}$ istraživačkih podataka o tome kako se ti koncepti i njihove teorije uklapaju u specifično hrvatsko iskustvo.

${ }^{27}$ Stoga smo uključili predstavnike politika u vidu stručnjaka iz ministarstava koja imaju najveći obujam financiranja organizacija trećeg sektora, stoga i aktivno surađuju, dodjeljuju sredstva i evaluiraju projekte. Osim toga, uključili smo predstavnike Vladinog ureda za udruge i Nacionalne zaklade za razvoj civilnog društva kao onih koje aktivno rade ne samo na alokaciji sredstava nego i razvoju trećeg sektora i imaju moguće ponajviše uvida u njegovo stanje i utjecaj. U uzorak su uključene glavne granske organizacije ili mreže koje imaju uvide u stanje zadruga, socijalnih poduzeća i ustanova. Intervjuirane su i osobe s dugogodišnjim iskustvom rada u sektoru koje su bile ili jesu predstavnici u Savjetu za razvoj civilnog društva, imaju uloge predstavnika organizacija civilnog društva pri Europskom gospodarskom i socijalnom odboru ili su dio organizacija koje su potporni resurs za razvoj trećeg sektora. Na kraju, u uzorak su uključeni po sličnoj logici predstavnici svih regionalnih zaklada koji potiču razvoj trećeg sektora. Oni imaju uvide o razvoju zakladništva, ali uslijed svog stalnog financiranja i evaluiranja utjecaja projekata u zajednici imaju informacije o utjecajima širokog kruga organizacija, posebice na lokalnoj razini. 
istraživača ${ }^{28}$. Nakon toga se dalje konceptualizirala empirijska supstanca kako bi se unutar tematskog okvira formirali pojmovi i veze među njima unutar tri podteme vezane za istraživačka pitanja: motivacija i potreba za mjerenjem utjecaja, kapaciteti različitih sudionika trećeg sektora za mjerenjem utjecaja te metode $\mathrm{i}$ alati mjerenja utjecaja.

Istraživanje je odobreno od nadležnog etičkog povjerenstva fakulteta te je vodilo računa o pitanjima informiranog pristanka i transparentnosti.

\section{MOTIVACIJA, POTREBA I KAPACITETI RAZLIČITIH DIONIKA U SEKTORU ZA MJERENJE UTJECAJA - REZULTATI ISTRAŽIVANJA}

\section{Motivacija za mjerenje utjecaja}

Različiti sudionici istraživanja percipiraju koje su potrebe i motivacija za mjerenjem utjecaja na razini organizacija i na razini sektora. U ovoj podtemi nalazimo pojmove legitimiteta u javnosti, legitimiteta prema donatorima te unaprjeđenja vlastitog djelovanja koji će biti ilustrirani iskazima sudionika.

Sudionici u istraživanju slažu se kako bi jedna od motivacija za mjerenjem utjecaja zasigurno bila povećanje legitimiteta u javnosti kako bi se bolje predstavili doprinosi sektora. Upravo se jednim dijelom slika koju sektor ima u javnosti vidi kao direktni poticaj za mjerenje.
KD ${ }^{29}$ : Utisak zapravo da postoje neke paušalne procjene, npr. udruge ništa ne doprinose, oni troše naše pare i tako, tako mislim da je dobro da se prema javnosti ide sa nekim konkretnim podacima stvarnog utjecaja.

KD2: Mislim da je važno mjeriti tako da možemo zapravo pokazati u javnosti, dakle pokazati dionicima koji su važni za civilno društvo, tu mislim javnu upravu, na poduzetnički sektor, na društvo općenito, da se vidi koliko i kako se radi, znači koliki je taj doprinos društvenoj zajednici.

KD11: A ljudi u današnje doba posebno u Hrvatskoj, posebno se meni vrlo često čini nerazumnim, ali sa stavom prema općenito civilnom društvu kao nečemu što je niškoristi, to može biti njihov jako važan argument, di se zapravo pokazuje njihova vrijednost, za legitimitet sektora.

KD16: Znači da se nekim rezultatima, često puta ljudi $i$ vide nešto i ustraju na nečem već zadatim, nečim već stečenim, nešto što se podrazumijeva da je tu. Ali, ne znaju da su zapravo organizacije civilnog društva iza toga stajale i da su one dovele te promjene očito za dobro drugih, za dobro određenih dijelova populacije i slično.

KD5: Apsolutno da je potrebno, meni je samo žao što to nismo davnih dana u sektoru definirali i odredili na koje načine mjeriti taj utjecaj. Mislim da se to u zadnje vrijeme intenziviralo, prije svega zbog negativne slike koje imaju organizacije civilnog društva.

Drugi važan aspekt potrebe za mjerenjem koji različiti sudionici u istraživanju

\footnotetext{
${ }^{28}$ Iako je uobičajeni postupak da se višestruko kodiranje vrši provjeravanjem strategije kodiranja i interpretacije rezultata od strane drugog nezavisnog istraživača (Barbour, 2001.), zbog karaktera istraživanja za doktorsku disertaciju to ovdje nije bilo adekvatno primijeniti. Odvojen postupak kodiranja odvijao se u različitim vremenima na originalnim zapisima intervjua te su se nakon postupka kodovi uspoređivali i donosila se odluka o stupnju njihovog slaganja i konačnom kodu za svaki od kodiranih dijelova građe, čime smo utjecali na povećanje pouzdanosti procesa analize.

${ }^{29}$ Sudionici intervjua, kako bi se sačuvala anonimnost, navode se pod kodovima KD1, koji označava ključnog sudionika 1, pa dalje po redoslijedu intervjuiranja do KD16.
} 
prepoznaju je legitimitet prema donatorima. U tom pogledu, novac koji treći sektor dobiva od donatora, $\mathrm{u}$ prvom redu $\mathrm{s}$ nacionalne i lokalne razine gleda se kao investicija koja treba pokazati koji tip povrata donosi. Implicira se da je povrat, u smislu ekonomskog ili društvenog utjecaja, ključna komponenta opravdanja novca koji pritječe u sektor. Bez demonstriranja povrata, sudionici na neki način prepoznaju da sektor može biti izložen pritiscima o svrsishodnosti svog postojanja.

KD1: Radi se o tome da mi htjeli, ne htjeli, u neprofitni sektor gledamo kao investiciju, s jednog dijela, dakle s te strane možemo vidjeti da veliki broj onih koji su donatori, koji financiraju, koji sudjeluju, dakle, u nekoj vrsti financiranja neprofitnog sektora ostaju kratkih rukava, tj. bez nekih adekvatnih rezultata koje je moguce mjeriti.

KD1: E sad, kad govorimo o milijardi kuna i da za tu milijardu kuna ne znate uopće osim financijskog pokazatelja koji je isto upitan, kada govorimo o vrednovanju njegovom i tom utjecaju... Vi zapravo uopće ne znate šta ste radili i samo eventualno znate da ste dobili izvještaje i da ti izvještaji, recimo, odstupaju u odnosu na ispunjavanje obveza ili ne.

KD5: Iz naše perspektive kao aktera, to je sigurno komunikacija prema van i komunikacija prema unutra, odnosno osvješćivanje što smo napravili. A donatorima, investitorima je negdje ključno $i$ važno vidjeti koji im je povrat na investiciju.

KD10: Ako se ne mjeri utjecaj, ako mi nemamo tu vrstu komuniciranja rezultata, stvarnih rezultata pojedinih projekata, onda je zapravo teško očekivati da će netko imati volje $i$ ambicije financirati, primjerice multipliciranje.

Osim toga, kao jedan od razloga zašto je potrebno mjeriti utjecaj organizacija trećeg sektora vidi se unaprjeđenje vlastitog djelovanja. Mjerenje kao takvo vidi se kao instrument povećanja kvalitete rada $\mathrm{u}$ organizacijama pružajući im povratnu informaciju o tome što su postigli i jesu li na pravom putu u ostvarivanju ciljeva ili podmirivanju potreba koje su si zadali.

KD11: Mislim da bi to bilo najkorisnije njima, da jednostavno učine svoj rad $i \mathrm{kva-}$ litetnijim $i$ vidljivijim $i$ transparentnijim. Jednostavno, to je njihov pečat, gdje je njihova vrijednost $u$ društvu.

KD5: Ne samo za popravak slike, nego to nam daje mogućnosti da znamo kakva bi nam bila strategija, šta moramo razvijati, gdje smo napravili ono što treba, gdje zaostajemo. I to se treba ujednačiti.

KD15: Naravno da postoji, ogromna potreba jer će ona pokazati $i$ kapacitet $i$ snagu koju ima u ovom slučaju civilni sektor i koji može napraviti utjecaj na razvoj zajednice. Sigurno je da treba to mjeriti....

\section{Kapaciteti različitih dionika za mjerenje utjecaja}

Osim percipirane potrebe za mjerenjem utjecaja, svakako su važan element mogućnosti razvoja područja trenutni kapaciteti na razini organizacija, sektora i provedbenih tijela. U ovoj podtemi nalazimo pojmove skromnih kapaciteta mjerenja utjecaja u organizacijama, manjka potpore i edukacije o mjerenju utjecaja, fokusa provedbenih tijela na administrativne zahtjeve, a ne mjerenje te usmjerenosti na praćenje trošenja sredstava koji će biti ilustrirani iskazima sudionika.

Mjerenje utjecaja kao takvo nije dovoljno osviješteno. Isto tako, ispitanici sugeriraju da su kapaciteti organizacija u tom pogledu skromni. Organizacije često pod mjerenjem utjecaja smatraju bazične evaluacije ili projektne izvještaje.

KD10: Međutim, udruge ili nemaju kapaciteta, neki put je zapravo to ključni pro- 
blem, oni nemaju kapacitet unutar udruge za kvalitetno mjerenje utjecaja. Ne poznaju ni alate, niti imaju vještine da bi mogli samostalno to raditi.

KD16: Bojim se da uopće nemaju niti sliku, a kamoli praksu na koji bi način pravilno prepoznali $i$ možda mjerili utjecaj. Osim što oni opet imaju obavezu prema generalnom donatoru, prema komisiji da daju sve svoje izvještaje, koji mogu sadržavati neke brojčane podatke.

KD6: To je valjda, isto ono kako je krenulo s donatorima da moraš imati evaluaciju unutarnju, pa je onda bilo i za vanjsku pa onda za financijsku reviziju u projektima koji su imali malo veće iznose, mislim da su donatori tu neku dimenziju uveli nego što su organizacije civilnog društva same osvijestile da bi trebale pratiti šta dugoročno postižu. Jer koliko sam uspio iščitati izvještaje o radu organizacija, neke organizacije koje imaju 10-godišnji izvještaj, 15 godina rada ili nešto, sve se bazira na grupiranju nekih podataka koji govore $u$ kratkoročnim rezultatima. Tipa znam da $i$ mi imamo tu neku zamku, tipa zbrajaju se brojevi korisnika po godinama.

Također, uvelike je problem što uslijed manjka kapaciteta ne postoji ni sustavna potpora kojom bi se omogućilo organizacijama da se educiraju o mjerenju utjecaja. Sugerira se da postoji velik prostor za stručni napredak u svim elementima mjerenja utjecaja.

KD4: Tako da mi na neke načine potičemo to, jedino prvenstveno bi trebalo prvo ponovno vratiti, znači $i$ informirati javnost o važnosti znači samog praćenja $i$ onda evaluiranja $i$ tu dati neka znanja. Kako odrediti, kako pratiti, kako evaluirati, koga angažirati za evaluaciju... Tako da, ali toga nema puno, zato što, znate vi trebate staviti nekog imenom i prezimenom, a taj mora stajati iza toga što je napravio. Iza toga izvještaja. A ne hvalospjeve o nečem što nije u stvari, upitno je da li je dobro.

KD10: A tu priča ima dvije dimenzije. Jedna je koliko su organizacije uopće svjesne potrebe za takvom edukacijom. Tu potrebu možda jasnije uočavaju oni koji financiraju nešto pa onda, kako što ja vama kažem da trebali bi mjeriti utjecaj. To je jedna razina priče. Meni se uvijek čini da nije njima uvijek najjasnije ni što ih pitamo, kada razgovaramo o takvim stvarima u obilascima, a drugi dio priče je dakle taj, koliko realno postoje kapaciteti na razini sektora da se takve primjerice edukacije organiziraju $i$ tko bi ih radio $i$ koliko mi u Hrvatskoj realno imamo ljudi koji bi mogli raditi taj tip edukacije.

$\mathrm{S}$ druge strane stoje provedbena tijela. Njihov fokus, prema onome što sudionici istraživanja navode, je u praćenju projekta, a ne evaluiranju utjecaja koji je postignut provođenjem tih projekata. U tom pogledu, često se više inzistira na administrativnim zahtjevima. Provedbena tijela često izabiru liniju manjeg otpora u raspisivanju i zahtjevima svojih natječaja. Drugi razlog je manjak kapaciteta i usmjerenosti na mjerenje utjecaja.

KD1: Naime, tu se vrlo često događaju greške, da osobe zadužene i agencija, hrvatskih agencija, inzistiraju na praćenju potpuno nebitnih stvari... Problem je kod praćenja europskih projekata što su orijentirani procesno, a ne kvalitativno, dakle, ne na učinak.

KD2: Apsolutno ne, mislim da nemaju nikakve konkretne kapacitete niti mislim da oni grade kapacitete u tom pogledu. Ono što iz našeg iskustva, mi najviše imamo kontakte sa HZZ-om, SAFU-om, evo, recimo, da su to dvije intenzivnije, to su administracije koja je dovedena do birokracije, gdje ona sama sebi postaje svrha, gdje više gubiš konce zapravo što treba, što ne treba, kažem ne mislim da imaju te kapacitete, ne 
mislim uopće da im je to preokupacija, ne mislim da smatraju mjerenje nekakvim važnim momentom,

KD14: Zato jer ponekad je možda nekima teško priznati na temelju objektivnih parametara da neke aktivnosti nisu bile targetirane ili nisu bile dobro provođene, ili jednostavno nema interesa, nekad se neke aktivnosti, pogotovo kada se na političkoj razini donesu iz razloga koji možda nisu najbolji, najargumentiraniji.

KD5: Kada vi danas pogledate bilo koji izvještaj, donator koji vam dostavi jako ćete malo staviti tih pokazatelja. Osim nekakvih brojčanih. Znači da li su to aktivnosti, nabrojat ćete aktivnosti, broj korisnika, $i$ tu $i$ tamo vam bude pitanje kakve ste promjene kod korisnika napravili, odnosno zajednicu u kojoj ste provodili.

KD11: Mislim da je to u redu, broj korisnika, broj aktivnosti, broj tiskanih nekih materijala. Ali, zapravo ne govore o kvaliteti nečijeg rada i zaista o pravom utjecaju. To meni nije dovoljno. Mislim da svi donatori i oni koji daju sredstva idu za tim, linijom manjeg otpora jer im je najlakše pratiti brojčane podatke, ali oni sigurno nisu dovoljno kapacitirani.

Kroz pozornost na namjensko trošenje sredstava ne pokazuje se učinkovitost alokacije u smislu proizvedenog utjecaja koji je posljedica te alokacije već samo učinkovitost potrošnje dodijeljenog novca.

KD10: Nažalost, čini mi se da dosta institucija u Republici Hrvatskoj koje provode nadzor zapravo praćenje provedbe odobrenih projekta, odnosno projekata koji su financirani iz javnih izvora u konačnici, prvenstveno prati namjensko trošenje sredstava, a utjecaj zapravo svode na te nekakve kvantitativne pokazatelje, jer opet taj dio čini mi se lakše komuniciraju na van.

KD4: Naravno da su administrativni kapaciteti svagdje mali, što $u$ svakom slučaju, osim što su veći to se veća pažnja napravi, što se tiče konkretnog mjerenja i rezultata i kontrole, financijske kontrole, odnosno namjenskog trošenja.

\section{Metode mjerenja utjecaja i status mjerenja}

U podtemi metode mjerenja utjecaja $\mathrm{i}$ status mjerenja nalazimo pojmove nerazvijenost i nekorištenje specifičnih alata i metoda u organizacijama, nedostatak sustavne kulture evaluacije, te fokusa na performanse organizacije, a ne utjecaj u provedbenim tijelima, koji će dalje u tekstu biti ilustrirani iskazima sudionika istraživanja.

U vidu prepoznatih ograničenih kapaciteta i samog sektora i provedbenih tijela ne čudi što često sudionici istraživanja ukazuju na nerazvijenost i nekorištenje specifičnih alata i metoda za mjerenje utjecaja. Konkretni alati i metode nisu na dnevnom redu organizacija koje uglavnom zadovoljavaju administrativne zahtjeve, dok s druge strane, ne postoje konkretne inicijative za njihovo razvijanje. Ono što se prati su većinom izlazni rezultati vezani za specifične aktivnosti projekta. Dijelom se očekuje da će EU natječaji staviti veći naglasak na mjerenje utjecaja.

KD11: Mislim, koliko sam komunicirao s ljudima, ljudi su svjesni te situacije, te potrebe i otvoreni su za nju. Mislim da velik dio njih ne mjeri svoj društveni utjecaj zato što nemaju alata, zato što ne znaju, nedostaje nam stvarno stručne i raznolike edukacije kako se to radi.

KD5: Vjerujte mi, sigurna sam da udruge ne znaju kojim se metodama mjeri to postignuće, odnosno utjecaj. One koje su malo razvijenije će možda nekakvim metodama intervjua, nekakvim fokus grupama vidjeti što su konkretno napravili i kakva je promjena nastala kod korisnika kojima pruža uslugu. A neke vam koje su manje 
razvijene, samo će vam nabrojati kvantitativno koliko su napravili usluga, koliko su korisnika imali. A to nije temelj da bi se neke promjene u društvu trajno dešavale.

KD15: Nisam sigurna da se netko time bavio, za sad smo svi nekako usmjereni za osnaživanje kapaciteta udruga za pisanje projekata, pisanje izvještaja, sastavljanje proračuna $i$ tu smo na jednom projektnom menadžmentu, ali upravo to mi se čini kao jedan dobar korak dalje, znači da se zaista možda počne i u tom smislu promišljati.

KD7: Malo veći naglasak pogotovo kroz korištenje Europskih fondova na pokazateljima utjecaja i tu se naravno krecemo najprije od onih bazičnih pokazatelja koje isto godinama nisu mjerili, bazičnih produkata projekata, bazičnih outputa što bi rekli.

KD2: Utjecaj za mene ja mislim da ono što mi pratimo u Hrvatskoj $i$ što pratimo kroz udruge jesu izlazni rezultati, znači koliko sudionika i sl., na razini nešto, sada sve manje, nažalost, moram ti reći, da se sve manje donatori pogotovo za Europske fondove, sve manje uopće ih zanima koji je outcome, koja je nekako promjena na razini outcoma, na razini specifičnog cilja, tako da o utjecaju ne mogu ni govoriti da se ovaj uopće mjeri u Hrvatskoj.

U hrvatskom kontekstu, mjerenje utjecaja organizacija je zbog svoje zapostavljenosti i nerazvijanja sustavne kulture evaluacije u toj mjeri stran koncept da može i sam izazvati određeno zaziranje i nepovjerenje. Također, kad se gledaju postignuća organizacija u trećem sektoru, najčešće se ne sagledava utjecaj, već se gledaju performanse organizacije na najnižim razinama indikatora.

KD6: Mislim da veliki broj organizacija razmišlja o tome, sve više $i$ više i mislim da se desio taj shift ili se dešava taj shift, nije važno zbog donatora nego je važno zbog nas samih. I to se osjeća u javnosti jer se propituje... A znaš mjeriti, taj poseban utjecaj u zajednici je isto neka perspektiva o kojoj se ne priča, o kojoj se ne radi. Možda i da ideš propitivati, možda bi bio osuđen, kaj sad ti propituješ sebe i svoje zasluge umjesto da si ono to je logično vrednuješ di si šta si i šta ćeš dalje naprijed.

KD2: Tu bih rekla, da mi izvještavamo o tome jesmo li postigli cilj prema logičkoj matrici, ali zapravo kada dolaze u kontrolu, oni ne gledaju, oni gledaju samo koliko se čega kupilo, financijski izvještaj je najvažniji, ove promjene, programski dio, koliko smo postigli zadane ciljeve.

KD1: S jedne strane imate pritiske Europske unije, Komisije jel, koja inzistira zapravo da način izvještavanja bude toliko detaljan, zapravo da ćete vjerojatno $u$ tom procesu izvještavanja biti primorani zapravo da vodite više brige na izvještavanje nego što radite. S druge strane, imate problem, dakle, javnih institucija lokalne samouprave, ministarstva, županije i ostalih davatelja, jel koji takorekuć ne da ne inzistiraju, nego zadovoljavaju, ali otprilike zadovoljavaju se formalno vašim pismenim izvještajem, koji najčešće i ne uspiju pročitat nego se zadovolje samo vašim slanjem izvještaja is tim smatraju da je vaš projekt završen... Dakle, naknadni proces vrednovanja ukupnog projekta ili kompletnog programa ne postoji.

KD7: Dakle, rekao bih da organizacije civilnog društva stoje pred izazovom boljeg izvještavanja, dakle naprosto se nova metodologija praćenja fondova Europske unije zasniva na tome da se pokazuju rezultati ulaganja, znači mora se uložiti više vremena u dokumentiranje tih rezultata da bi se onda moglo, naravno, is vremenom $i$ mjeriti utjecaj. Zapravo većina organizacija u svakodnevnom radu po prvi put mora točno pratiti po pojedinim kategorijama korisnika kako programi po provedbi utječu na njih i nakon provedbe projekta, kakav 
je njihov potencijal za zapošljavanje, što se zapravo dogodilo sa ulaganjem. To je ono što nismo dugo godina pratili, ali evo najvećim dijelom ipak pod utjecajem korištenja Europskih fondova ta vrsta metodologije dolazi na dnevni red.

\section{RASPRAVA ISTRAŽIVAČKIH REZULTATA}

Za organizacije trećeg sektora i volontiranje se misli da doprinose mnogim od dimenzijama socio-ekonomskog razvoja Hrvatske (Baturina, 2016.), ali premalo je dosljednosti postignuto u sustavima za mjerenje tih utjecaja, čineći teškim dokazati utjecaje ili napraviti sustavne usporedbe. Rezultati istraživanja pokazuju da su kapaciteti i organizacija i provedbenih tijela za mjerenje utjecaja skromni. Fokus provedbenih tijela, prema onome što sudionici istraživanja navode, je u praćenju projekata, a ne evaluiranju utjecaja koji je postignut provođenjem tih pojedinih projekata ili skupom projekta. U tom pogledu, često se više inzistira na administrativnim zahtjevima koji otežavaju organizacijama svakodnevni rad, dok se ne obraća puno pozornosti na promjene koje donosi provedba tih projekata. Istraživanje (Bežovan i sur., 2016.b) također ističe da birokratski zahtjevi predstavljaju sve veće opterećenje za organizacije u sektoru. Birokratski zahtjevi i daljnja profesionalizacija mogu utjecati na stvaranje poticaja za organizacije da oblikuju svoje djelovanje oko uvjeta ugovara prije nego potreba klijenata (McHugh i sur., 2013.). U sektoru imamo bujanje administrativnih zahtjeva povezanih s prijavom, provedbom i izvještavanjem na projektima. Kontrola tim oruđima često se povećava sa zahtjevima EU fondova, ali i manjkom povjerenja prema sektoru koje uzrokuje pretjeranu normiranost. Veći fokus stavlja se na formalne zahtjeve natječaja, koji uvelike stvaraju teret organizacijama u sektoru.

Ne postoje konkretne inicijative za razvijanje mjerenja utjecaja. Izvještavanju i koracima koji bi vodili k mjerenju utjecaja ne posvećuje se pažnja. Stoga ispitanici, bez obzira na područje djelovanja, nisu blizu formuliranja načina mjerenja utjecaja. Tema mjerenja utjecaja, vođena prije svega motivacijom za povećanjem legitimiteta sektora u javnosti, stidljivo se pojavljuje u promišljanjima sudionika bližih sektoru. $U$ hrvatskom kontekstu, ispitanici, iako na odgovornim položajima, nemaju koncepciju kako mjeriti utjecaj te nisu osviješteni koliki je puni značaj mogućeg mjerenja utjecaja za doprinos razvoju njihovih područja djelovanja. U provedbenim tijelima ta tema nije na dnevnom redu te se ne ulaže u razvoj kapaciteta za mjerenje utjecaja.

S druge strane, organizacije se najčešće uključuju u evaluacije ako se to od njih zahtijeva ili imaju specifično dostupno financiranje za te namjene. Iako postoje brojni alati prilagođeni različitim tipovima organizacija i njihovih svrha djelovanja, taj aspekt ne samo da se ne koristi, nego i u diskursu djelovanja organizacija još uvijek niti ne prepoznaje kao bitan. Konkretni alati i metode nisu na dnevnom redu organizacija koje uglavnom zadovoljavaju administrativne zahtjeve. ${ }^{30}$

U hrvatskom kontekstu, mjerenje utjecaja organizacija je uslijed svoje zapostavljenosti i nerazvijanja sustavne kulture evaluacije stran koncept koji je daleko od

\footnotetext{
${ }^{30}$ Što pokazuju i primjeri studija slučaja organizacija trećeg sektora provedenih o okviru šireg istraživanja doktorske disertacije. Iako je u uzorku bilo šest razvijenih organizacija trećeg sektora, prakse kao i alati mjerenja utjecaja nisu ni razvijeni ni korišteni. Organizacije su svjesne potreba i imaju određene planove za napredak u tom području (Baturina, 2016.).
} 
promišljanja širih dionika sektora ${ }^{31}$ te se još uvijek od njega »bježi« Također, kada se gledaju postignuća organizacija u trećem sektoru, najčešće se ne sagledava utjecaj, već se gledaju performanse organizacije na najnižim razinama indikatora. Stoga se može reći da postoji velik prostor za daljnje osvještavanje i razvoj prakse. No, ne postoje konkretne inicijative za njezino razvijanje. $^{32}$

U mjerenju utjecaja važan aspekt su i resursi koje organizacije ili istraživači imaju na raspolaganju kako bi proveli mjerenje. Mjerenja zahtijevaju precizno određivanje troškova koji dijelom ovise o specifičnim fiskalnim ili regulatornim aranžmanima. Takvi programi utvrđivanja troškova su izuzetno složene vježbe (Greffe, 2003.). Mjerenje utjecaja često ima velike zahtjeve za organizaciju, stoga će resursi koji stoje na raspolaganju određivati i tip mjerenja. Manje organizacije mogu biti u neprilikama zbog poteškoća poput troška, vremena i napornog rada koji su uključeni u aktivnosti da bi se s njima bavilo na zadovoljavajući način. Osim toga, opasnost je da se ide linijom manjeg otpora imajući u vidu skupine u posebno teškom položaju, posebno u hrvatskom kontekstu gdje su vidljivi određeni trendovi profesionalizacije i projektizacije (Bežovan i sur., 2016.). Organizacije koje profesionalno pišu projekte mogu djelovati po principu »efekta ubiranja vrhnja« za one skupine za koje je lako raditi projekte. Zaključak se posebice odnosi na socijalno ugovaranje i moguće nove mehanizme financiranja. O toj moguće neintendiranoj posljedici treba voditi računa.
Mjerenje utjecaja je jednim dijelom i politički proces jer pokazuje koliko smo napredovali prema nekom deklariranom cilju te kakav je karakter (ili uspješnost) procesa kojima pokušavamo ostvariti te ciljeve. Jedan od glavnih razloga za naizgled ograničenu sofisticiranost metoda procjene utjecaja čini se da je nedostatak političke predanosti važnosti procjena društvenog i ekonomskog utjecaja ${ }^{33}$ i, u vezi s ovim, ograničenih proračuna, vremena i kapaciteta koji su na raspolaganju da se poduzme detaljna analiza problema u pitanju (ECORYS, 2010.). U Hrvatskoj je na djelu općenit manjak političke volje i izgrađenosti struktura koje bi promovirale meritokratska načela. Nedostatak takvog interesa pridonosi brojnim problemima $\mathrm{s}$ funkcioniranjem različitih aspekata društva i ne tiče se samo trećeg sektora, nego prije opće političke kulture manjka socijalnog dijaloga (Stubbs i Zrinščak, 2005.) i poštovanja principa dobre vladavine.

\section{ZAKLJUČAK - PREMA NAPRETKU U MJERENJU UTJECAJA TREĆEG SEKTORA}

Na neki način može se reći da postoji konsenzus među sudionicima $u$ istraživanju o tome da je evidentna potreba za mjerenjem utjecaja sektora. Različiti sudionici istraživanja percipiraju koje su potrebe i motivacija za mjerenjem utjecaja na razini organizacija i na razini sektora. Demonstriranjem utjecaja sektor bi mogao povećati svoj legitimitet i dijelom utjecati na negativnu sliku koja postoji u javnosti.

\footnotetext{
${ }^{31}$ Postoji primjer neformalne Radne skupine koju je inicirala Nacionalna zaklada za razvoj civilnog društva na temu mjerenje društvenog utjecaja. No, oni na kraju nisu napravili pomake u tom području.

${ }^{32}$ Iako trenutno neformalno djeluje Hrvatska evaluatorska mreža koja razvija svoje aktivnosti i bit će prirodan prostor za osnaživanje područja mjerenja utjecaja, barem sa strane evaluatora.

${ }^{33}$ Dobar primjer toga u našem kontekstu je i status Ureda za koordinaciju sustava procjene učinka propisa koji se, iako bi trebao imati puno značajniju ulogu u evaluiranju učinaka i utjecaja politika, našao pod medijskom hajkom koja ga je proglašavala nepotrebnim. Takav javni diskurs je dijelom prepreka razvoju politika temeljenih na dokazima, a time i praksi mjerenja utjecaja.
} 
Također, koristi mjerenja utjecaja vide se i u većem legitimitetu prema donatorima. U tom pogledu, treći sektor mogao bi jasnije povezati utjecaje koje donosi s novcem koji mu stoji na raspolaganju i tako dijelom odgovoriti na sumnje koje dolaze s različitih razina koje idu čak do optužbi za pranje novca. Osim toga, sudionici jasno vide da bi i procesi mjerenja utjecaja mogli djelovati i na samu organizaciju, povećavajući joj transparentnost te kvalitetu rada i vladavine. Sudionici istraživanja vide razloge mjerenju koji su već prepoznati u literaturi (Harlock, 2013.; Ebrahim i Rangan, 2014.; Bassi i Vicenti, 2015.) te su motivacije i pobude na mjerenje sukladne diljem sektora $u$ različitim zemljama.

U Hrvatskoj, s obzirom na manjak tradicija mjerenja utjecaja, predstoji proći cijeli proces konstrukcije na kakav način želimo mjeriti utjecaj, koje su glavne dimenzije prema kojima će se usmjeriti napori i podrška te identificirati indikatore. Ovaj rad je i toj namjeri manji prilog. Što se tiče uloge različitih dionika, akademski sektor u ovom području razvija istraživanja sporo (Bežovan et al., 2016.b; Baturina, 2016.), i tek poticaj i uključivanje u međunarodnu komparativnu praksu i učenje iz iskustva drugih može donijeti određene pomake. Policy razina površno promatra utjecaj, kroz izvještavanje koje se ne prati na adekvatan način, već što se utjecaja tiče, zadržava se na bazičnim indikatorima. Praktičari su dijelom osviješteni i koriste delegirani novac u proračunima projekata uglavnom za evaluacije, no nemaju razvijene prakse, zbog metodoloških poteškoća. Može se reći da se produbljuju preliminarni uvidi istraživanja (Glavina Petričević, 2014.) koji govore o potrebi, ali nedovoljno razvijenoj praksi. Ova analiza trebala bi u tom pogledu biti poticaj za daljnji razvoj prakse.
Gledajući iz pozicije doprinosa rada i napretka u mjerenju utjecaja sektora, bitno je dati određene preporuke i prijedloge.

Na mikrorazini je moguće najizglednije promovirati mjerenje utjecaja. U tu svrhu, na razini organizacija je adekvatnije primjenjivati autonomne procjene utjecaja koje bi omogućile samim organizacijama da izabiru indikatore prema svojim ciljevima i metode koje drže prikladnima, a poštuju načelo reciprociteta, da su zahtjevi za mjerenjem sukladni s obzirom na veličinu i mogućnosti organizacije. Mjerenje utjecaja na mikrorazini moglo bi se osloniti na korištenje alata za izvještavanje prvenstveno kako bi pokazali utjecaji na dobrobit korisnika. Prijedlog je na neki način da se napravi odmak od evaluacija koje pojedine organizacije koriste prema specifičnijem mjerenju utjecaja. No, za to trebaju biti ostvareni određeni preduvjeti. Prvenstveno, organizacije trebaju imati definirane svoje strateške ciljeve prema kojima bi mogle mjeriti utjecaj. Drugi preduvjet tiče se resursa i kapaciteta. Stoga treba voditi računa o razvijanju sustava potpore za mjerenje utjecaja, kao i obrazovanju u tom području. Potpora treba doći od samih organizacija, potpornih mreža, ali i od provedbenih tijela s kojima organizacije trebaju biti u bliskoj komunikaciji kako bi se mjerenje utjecaja učinilo suradničkim pothvatom.

Za mezorazinu prijedlog je sagledavati utjecaje s razine politika, po pojedinim područjima, primjerice, kao što su socijalna skrb i socijalno uključivanje, obrazovanje, kultura ili pak ekologija. Naime, sektor je izrazito heterogen i s obzirom na kapacitete za mjerenje utjecaja ovaj pristup čini se prikladnijim. Tu se može, prema ciljevima organizacija i ciljevima područja koji se definiraju u njima relevantnim strategijama i politikama, napredovati prema konstruiranju indikatora za praćenje i mjerenje. To bi u početku zahtijevalo fragmentiranije $i$ 
fleksibilnije praćenje utjecaja kako bi se kasnije moglo jačati kapacitete za veću integraciju. Pristup i indikatori bili bi heteronomni u smislu da bi bili izvanjski organizacijama, razvijeni od strane provedbenih dijela, dionika politika odgovornih za područja i akademskog sektora, ali ipak i uz upliv i povratnu informaciju praktičara. Takav pristup bi se dalje razvijao s vremenom i iskustvom i mogao generirati dokaze visoke kvalitete. On bi bio dostižan korak naprijed u unaprjeđenju mjerenja utjecaja $u$ našem kontekstu. No, ne ohrabruje postojeća razina horizontalne komunikacije među ministarstvima $\mathrm{i}$ drugim provedbenim tijelima, što u ovom trenutku može značajno ograničiti takav pothvat. Na mezorazini moguće je podatke o utjecaju u specifičnim područjima nadopunjavati preko studija slučaja. Agregacije slučajeva i njihova usporedba s drugim kontekstima svakako će pridonijeti većoj valjanosti ovog pristupa mjerenju (Baturina i Bežovan, 2015.).

$\mathrm{Na}$ makrorazini utjecaj trećeg sektora je više implicitan nego dokazan. I na razini Europe on je raspršen i nejasan (Enjolras i sur., 2016.). Uslijed naglašenih metodoloških ograničenja postavlja se pitanje je li uopće mjerenje utjecaja cijelog sektora u svim dimenzijama na toj analitičkoj razini moguće ili je na nekih način nedostižna iluzija koju gaje istraživači u sektoru. Osim značajnog unaprjeđenja statističkog praćenja opsega i aktivnosti sektora koje je nužno, ovaj vid sagledavanja utjecaja sektora u Hrvatskoj se za sada čini kao »Pandorina kutija« čije bi otvaranje donijelo moguće više novih nedoumica nego odgovora. Agregiranje utjecaja cijelog sektora zasigurno iziskuje mnogo veće dosege razvoja praksi mjerenja nego što je trenutni kapacitet u Hrvatskoj i stoga bi prema njemu trebalo napredovati postepenim koracima, prateći i učeći iz iskustava drugih europ- skih zemalja s razvijenijim praksama mjerenja.

Za daljnje napredovanje prakse mjerenje utjecaja, bar kao dobrovoljni trud organizacija i javnih tijela, već bi sada trebalo početi diseminirati kako bi se stvorila ne samo navika, već kritična masa dijaloga o toj temi, i mogućnost učenja iz vlastitih, ali i iz iskustava drugih. Nužno je naći načina kako bi se bolje koristili postojeći podatci. Pri tom je značajna suradnja s Hrvatskim zavodom za statistiku na otkrivanju informacija koje trenutno postoje o trećem sektoru i napredak prema uspostavljanju posebnog satelitskog (pod)računa za treći sektor unutar sustava nacionalnih računa.

Mjerenje utjecaja je moguće jedan od najkonkretnijih koraka koji bi mogao vratiti poljuljano povjerenje u sektor $u$ Hrvatskoj. Naime, konkretno mjerenje za sobom donosi i mogućnost jako vidljive javne demonstracije rezultata djelovanja sektora. Ona za sada često ovisi o sporadičnim medijskim napisima, koji više interesa imaju za pojedini skandal nego svakodnevne primjere dobre prakse. Mjerenje utjecaja može biti snažan argument u borbi za povjerenje i pozitivnu sliku sektora.

Opseg praksi mjerenja utjecaja za sada je ograničen. Mjerenje je značajan izazov za početnike i zajednicu koja nema razvijene standardne prakse, i nije do sada značajnije bila uključena u mjerenje utjecaja. Stoga s obzirom na to da je mjerenje utjecaja nerazvijeno u Hrvatskoj preporučuje se $\mathrm{i}$ isprobavanje različitih pristupa, vrednovanje povratnih informacija o njihovoj uspješnosti i otvoren kritički dijalog o njihovoj adekvatnosti i ograničenjima. Bilo bi značajno pristupiti razvoju mjerenja utjecaja čim prije kako bi se s vremenom povećavala kompleksnost, obuhvat i rigoroznost mjerenja. 


\section{LITERATURA}

Achleitner, A. K., Bassen, A., \& Roder, B. (2009). An integrative framework for reporting in social entrepreneurship. Available at https:// papers.ssrn.com/sol3/papers.cfm? abstract_ id $=1325700$

Barbour, R. S. (2001). Checklist from improving riguor in qualitative research: A case of tailwagging the dog?. BMJ, 322(7294), 1115-1117. bmj.322.7294.1115

Bassi, A., Lori, M., \& Vannini, I. (2014). Profiling the social impact of nonprofit institutions: measurement, constraints and research directions. The International Society for Third Sector Research, 11th international conference, July 22-25 2014, Munster. Dostupno na https://c. ymcdn.com/sites/istr.site-ym.com/resource/ resmgr/WP2014/ Profiling_the_social_impact_pdf

Bassi, A., \& Vincenti, G. (2015). Toward a new metrics for the evaluation of the social added value of social enterprises. CIRIEC-España, Revista de Economía Pública, Social y Cooperativa, 83, 9-42. Available at http://www. redalyc.org/html/174/17440036002/

Baturina, D. (2016). Utjecaj trećeg sektora na socio-ekonomski razvoj Republike Hrvatske (doktorska disertacija). Pravni fakultet, Zagreb.

Baturina, D., \& Bežovan,G. (2015). Social Innovation Impact - review No. 9. Seventh Framework Programme (grant agreement 613034), European Union. Brussels: Third Sector Impact.

Bežovan, G. (2005). Civilno društvo (2. izd.). Zagreb: Nakladni zavod Globus.

Bežovan, G., Ledić, J., \& Zrinščak, S. (2011). Civilno društvo u sveučilišnoj nastavi. Hrvatska i komparativna javna uprava, 11(1), 173-202. https://hrcak.srce.hr/132536

Bežovan, G. \& Matančević, J. (2011). Izgradnja identiteta: izazovi profesionalizacije organizacija civilnog društva. Civicus-ov Indeks civilnog društva u Hrvatskoj (istraživački izvještaj). Zagreb: CERANEO.

Bežovan, G., Matančević, J., \& Baturina, D. (2014a). Varaždin. In A. Evers, B. Ewert \&
T. Brandsen (Eds.), Social innovations for social cohesion: transnational patterns and approaches from 20 European cities. Liege: EMES.

Bežovan, G., Matančević, J., \& Baturina, D. (2014b). Zagreb. In A. Evers, B. Ewert \& T. Brandsen (Eds.), Social innovations for social cohesion: transnational patterns and approaches from 20 European cities. Liege: EMES.

Bežovan, G., Matančević, J., \& Baturina, D. (2016a). Socijalne inovacije kao doprinos jačanju socijalne kohezije i ublažavanju socijalne krize u europskim urbanim socijalnim programima. Revija za socijalnu politiku, 23 (1), 61-80. https://doi.org/10.3935/rsp.v23i1.1279

Bežovan, G., Matančević, J., \& Baturina, D. (2016b). External and Internal barriers to Third Sector Development - Croatia. Working paper part of work package 5 "External and Internal barriers to Third Sector Development" of the research project entitled Third Sector Impact.

Bežovan, G., \& Zrinščak, S. (2007). Civilno društvo u Hrvatskoj. Zagreb: Hrvatsko sociološko društvo.

Borzaga, C., \& Defourny, J. (Eds.). (2001). The Emergence of Social Enterprise. London: Routledge.

Brajdić Vuković, M., Ančić, B., \& Domazet, M. (2014). Podrška: trajni učinak ili poticajni trenutak? Društveni $i$ gospodarski učinci podrški Nacionalne zaklade za razvoj civilnoga društva. Zagreb: Nacionalna zaklada za razvoj civilnoga društva.

Brandsen, T. (2008). The third sector and the delivery of public services: An evaluation of different meta-theoretical perspectives. In P. Osborne (Ed.), The third sector in Europe. London: Routledge.

Centar za razvoj neprofitnih organizacija. (2017). Indeks održivosti OCD-a u Hrvatskoj za 2016. godinu. Zagreb: CERANEO.

Chaves, R., \& Monzón, J. L. (2012). Beyond the crisis: The social economy, prop of a new model of sustainable economic development. Service Business, 6(1), 5-26. https://doi. org/10.1007/s11628-011-0125-7 
Corry, O. (2010). Defining and theorizing the third sector. In R. Taylor (Ed.), Third Sector Research. New York: Springer.

Creswell, J. W. (2003). Research design: Qualitative, quantitative, and mixed methods approaches. Thousand Oaks, CA: Sage.

Defourny, J., \& Nyssens, M. (2010). Conceptions of social enterprises and social enterpreneurship in Europe and in the United States; convergences and divergences. Journal of social enterpreneurship, 1(1), 32-53. https://doi. org/10.1080/19420670903442053

Defourny, J., \& Nyssens, M. (2016). Fundamentals for an International Typology of Social Enterprise Models. ICSEM Working Papers, No. 33. Liege: The International Comparative Social Enterprise Models (ICSEM) Project.

Dekker, P. (2004). The Netherlands. From private initiatives to non-profit hybrids and back? In A. Evers \& J.-L. Laville (Eds.), The Third Sector in Europe. Cheltenham: Edward Elgar.

DiMaggio, P. (2001). Measuring the impact of the nonprofit sector on society is probably impossible but possibly useful. A sociological perspective. In P. Flynn, V. Hodgkinson (Eds.), Measuring the Impact of the Nonprofit Sector. New York: Kluwer Academic.

Dufour, B. (2015). State of the art in social impact measurement: Methods for work integration social enterprises measuring their impact in a public context. Paper presented at 5th EMES International Research Conference on Social Enterprise, Helsinki, 30.06.-03-07.2015.

Đokić, I., \& Sumpor, M. (2013). The role of Croatian civil society organisations in the European Union accession process. Zagreb: TACSO.

Ebrahim, A., \& Rangan, V. K. (2010). The limits of nonprofit impact: A contingency framework for measuring social performance. Harvard Business School Working Paper, 10-099. https://doi.org/10.2139/ssrn.1611810

Ebrahim, A., \& Rangan, V. K. (2014). What impact? A framework for measuring the scale and scope of social performance. California Management Review, 56(3), 118-141. https:// doi.org/10.1525/cmr.2014.56.3.118

Ecorys. (2010). Review of Methodologies Applied for the Assessment of Employment and Social Impacts. IZA Research Report, No. 28 Brusse1s: ECORYS.
Eurodiaconia. (2010). Measuring social value. What do we mean by measuring social value? London: DEMOS.

Edwards, M., Onyx, J., Maxwell, H., \& Darcy, S. (2012). Meso level social impact: Meaningful indicators of community contribution. Cosmopolitan Civil Societies Journal, 4(3), 18-37. https://doi.org/10.5130/ccs.v4i3.2576

Elkington, J. (2004). Enter the triple bottom line. In A. Henriques \& J. Richardson (Eds.), The Triple Bottom Line. Does it all add up?. London: Earthscan.

Enjolras, B. (2015). Measuring the impact of the third sector: From concept to metrics. TSI Working Paper, No. 5, Seventh Framework Programme (grant agreement 613034), European Union. Brussels: Third Sector Impact.

European Commission. (2012). Work Programme 2013 (Revision) Cooperation Theme 8 SocioEconomic Sciences and Humanities. European Commission C(2012) 9371 of 14 December 2012.

European Commission. (2013). Social impact measurement. Opinion of the European Economic and Social Committee. Brussels: European Commission.

European Commission. (2015). Policy brief on social impact measurement for social enterprises policies for social entrepreneurship. Luxembourg: Publications Office of the European Union.

Etizioni, A. (1973). The third sector and the domestic missins. Public Administration Review, 33(4), 314-323. https://doi.org/10.2307/975110

Evers, A. (1995). Part of the welfare mix: The third sector as an intermediate area. Voluntas, 6(2), 159-182. https://doi.org/10.1007/BF02353995

Evers, A., \& Laville, J. (2004). Defining the third sector in Europe. In A. Evers \& J-L. Laville (Eds.), The third sector in Europe. Cheltenham: Edward Elgar.

Franc, R., Sučić, I., Međugorac, V., \& Rihtar, S. (2012). Vidljivost i javna percepcija udruga $u$ Hrvatskoj 2012. Zagreb: SIPU International AB - TACSO ured u Hrvatskoj.

Gabarino, S., \& Holland, J. (2009). Quantitative and qualitative methods in impact evaluation and measuring results. London: UK Department for International Development. 
Glavina Petričević, S., \& Magdalenić, S. (2014). Izvještavanje o društvenom utjecaju - potreba za standardizacijom. Prezentacija na konferenciji Društveni utjecaj organizacija civilnoga društva u Republici Hrvatskoj, 25. 9. 2014, Zagreb.

Greffe, X. (2003). Innovation, value added and evaluation in the third system. A European Perspective. In The Non-profit Sector in a Changing Economy. Paris: OECD.

Harlock, J. (2013). Impact measurement practice in the UK third sector: A review of emerging evidence. Third Sector Research Centre Working Paper, 106. Birmignham: Third Sector Research Centre.

Jenei, G., \& Kuti, E. (2008). The third sector and civil society. In S. P. Osborne (Ed.), The Third Sector in Europe. Prospects and challenges. London: Routledge.

Jindra R., Munjiza E., \& Peko, A. (2007). Utjecaj volontera $u$ kreiranju uvjeta izgradnje mira $i$ zajednice u multietničkim zajednicama. Osijek: Centar za mir, nenasilje i ljudska prava.

Kaplan, R. S. (2001). Strategic performance measurement and management in nonprofit organizations. Nonprofit Management and Leadership, 11(3), 353-370. https://doi. org/10.1002/nml.11308

Krlev, G., Münscher, R., \& Mülbert, K. (2013). Social Return on Investment (SROI): State-ofthe-Art and Perspectives. CSI Report.

Lampkin, L. M., Winkler, M. K., \& Kerlin, J. (2006). Building a common outcome framework to measure nonprofit performance. Washington, D.C.: The Urban Institute.

Lorentzen, H. (2010). Sector labels. In R. Taylor (Ed.), Third Sector Research. New York: Springer.

Maas, K., \& Liket, K. (2011). Social impact measurement. Classification of methods. In R. L. Burritt, S. Schaltegger, M. Bennett, T. Pohjola \& M. Csutora (Eds.), Environmental Management Accounting and Supply Chain Management. New York: Springer.

Maier, F., Schober, C., Simsa, R., \& Millner, R. (2014). SROI as a method for evaluation research: Understanding merits and limitations. Voluntas, 26(5), 1805-1830. https://doi. org/10.1007/s11266-014-9490-X
Manetti, G. (2014). The role of blended value accounting in the evaluation of socio-economic impact of social enterprises. Voluntas, 25(2), 443-464. https://doi.org/10.1007/ s11266-012-9346-1

McHugh, N., Sinclair, S., Roy, M., Huckfield, L., \& Donaldson, C. (2013). Social impact bonds: A wolf in sheep's clothing?. Journal of Poverty and Social Justice. 21(3), 247-257. https://doi. org/10.1332/204674313X13812372137921

Milas, G. (2005). Istraživačke metode u psihologiji $i$ drugim društvenim znanostima. Zagreb: Naklada Slap.

Nacionalna zaklada za razvoj civilnog društva. (2009). Procjena stanja razvoja civilnoga društva u Republici Hrvatskoj u 2009. godini. Zagreb: Nacionalna zaklada za razvoj civilnog društva.

Nacionalna zaklada za razvoj civilnog društva. (2011). Procjena stanja razvoja organizacija civilnoga društva u Republici Hrvatskoj. Izvještaj istraživanja u 2011. godini. Nacionalna zaklada za razvoj civilnog društva.

National Endowment for Science, Technology and the Arts. (2013). Nesta standard of Evidence. London: NESTA.

Nicholls, A. (2009). We do good things, don't we?: Blended value accounting in social entrepreneurship. Accounting, Organizations and Society, 34(6-7), 755-769. https://doi. org/10.1016/j.aos.2009.04.008

Organisation for Economic Co-operation and Development. (2003). The Non-profit Sector in a Changing Economy. Paris: OECD.

Olsen, S., \& Galimidi, B. (2008). Catalog of approaches to impact measurement. Assessing social impact in private ventures. Social Venture Technology Group with the support of The Rockefeller Foundation. New York: The Rockefeller Foundation.

Ormiston, J., \& Seymour. R. (2011). Understanding value creation in social entrepreneurship: The importance of aligning mission, strategy and impact measurement. Journal of Social Entrepreneurship, 2(2), 125-150. https://doi.or g/10.1080/19420676.2011.606331

Patton, M. Q. (2002). Qualitative Research \& Evaluation Methods. London: Sage. 
Petak, Z., \& Vidačak, I. (2015). The political and institutional determinants of civil society development in Croatia since the 1980s. In D. Fink-Hafner (Ed.), The Development of Civil Society in the Countries on the Territory of the Former Yugoslavia since the 1980s. Ljubljana: Politika.

Rey Garcia, M. (2008). Evaluating the organizational performance and social impact of third sector organizations: A new functional realm for nonprofit marketing. Paper presented at the 8th International Conference of the International Society for Third Sector Research.

Rinaldo, H. (2010). Getting started in social impact measurement. A guide to choosing how to measure social impact. Norwich: The Guild.

Ritchie, J., \& Lewis, J. (Eds.). (2003). Qualitative research practice: A guide for social science students and researchers. London: Sage.

Salamon, L. M. (1995). Partners in public service. Government-nonprofit relations in the modern welfare state. Baltimore, London: The Johns Hopkins University Press.

Salamon, L. M., \& Anheier, H. K. (1997). In search of the non-profit sector: The question of definitions. In L. Salamon \& H. K. Anheier (Eds.), Defining the Non-profit Sector: A Cross-national Analysis. Manchester: Manchester University Press.

Salamon, L. M., \& Sokolowski, S. W. (2014). The Third Sector in Europe: Towards consensus conceptualization. TSI Working Paper Series, No. 2. Seventh Framework Programme (grant agreement 613034), European Union. Brusse1s: Third Sector Impact.

Salamon, L. M., Sokolowski, S. W., \& Anheier, H. K. (2004). Global civil society: Dimensions of the nonprofit sector (Volume II). Bloomfield, CT: Kumarian Press.

Simsa, R., \& Rauscher, O. (2014). Methodological guideline for impact assessment. TSI Working Paper Series, No. 1. Seventh Framework Programme (grant agreement 613034), European Union. Brussels: Third Sector Impact.

Stiglitz, J. E., Sen, A., \& Fitoussi, J.-P. (2009). Report by the Commission on the Measurement of Economic Performance and Social Progress. Dostupno na www.stiglitz-sen-fitoussi.fr
Stubbs, P., \& Zrinščak,S. (2005). Proširena socijalna Europa? Socijalna politika, socijalna uključenost i socijalni dijalog u Hrvatskoj i Europskoj uniji. U K. Ott (ur.), Pridruživanje Hrvatske Europskoj uniji: Ususret izazovima pregovora. Zagreb: Institut za javne financije; Zaklada Fiedrich Ebert.

Škrabalo, M. (2006). Izgradnja mira i razvoj zajednice - povezanost pristupa. U M. Škrabalo, N. Miošić Lisjak \& J. Papa (ur.), Mobilizacija i razvoj zajednice - akcijsko istraživanje u Hrvatskoj.. Zagreb: MAP.

Vanclay, F. (2003). International principles for social impact assessment. Impact Assessment and Project Appraisal, 21(1), 5-12. https://doi. org/10.3152/147154603781766491

Wainwright, S. (2002). Measuring impact: A guide to resources. London: NCVO Publications.

White, H., \& Barbu, A. (2006). Impact evaluation - The experience of the Independent Evaluation Group of the World Bank. Washington, D.C.: World Bank. Available at http://documents.worldbank.org/curated/ en/475491468138595632/Impact-evaluationthe-experience-of-the-independent-evaluation-group-of-the-World-Bank

Wood, C., \& Leighton, D. (2010). Measuring social value the gap between policy and practice. London: DEMOS.

Wuthnow, R. (1991). The voluntary sector: Legacy of the past, hope for the future? In R. Wuthnow (Ed.), Between States and Markets. The Voluntary Sector in Comparative Perspectives. Princeton: Princeton University Press.

Zappalà, G., \& Lyons, M. (2009). Recent approaches to measuring social impact in the third sector: An overview. CSI Background $\mathrm{Pa}$ per, No. 5. Sydney: Centre for Social Impact, University of New South Wales.

Zimmer, A., \& Evers, A. (2010). How do third sector organizations deal with change? Perspectives from five countries in three policy fields. In A. Evers \& A. Zimmer (Eds.), Third sector organizations facing turbulent environments. Baden Baden: Nomos.

Zimmer, A., \& Freise, M. (2006). Bringing society back in: Civil society, social capital, and third sector. Munster: Nachwuchsgruppe Europäische Zivilgesellschaft. 


\title{
Summary
}

\section{PERSPECTIVES OF THE THIRD SECTOR IMPACT IN CROATIA}

\author{
Danijel Baturina \\ Department of Social Work, Faculty of Law, University of Zagreb \\ Zagreb, Croatia
}

This paper examines the perspectives of third sector impact measurement in Croatia. Firstly, the third sector was briefly conceptualized as a new concept in the Croatian context, with methodological and other challenges for its measurement, as well as the development of the current approaches to third sector impact measurement. The qualitative empirical research results show that there is a consensus among research participants that there is an evident need for the sectors 'impact measurement in order to increase legitimacy in the public and towards donors, but also to enhance the work of organizations. However, the capacities of organizations and implementing bodies are modest. Concrete tools and methods are not on the agenda of the organizations and it can be concluded that the area of impact measurement is underdeveloped. Apart from the results, the paper also gives recommendations for the advancement of impact measurement practice with regard to the status of the third sector and the specificity of the Croatian context.

Key words: third sector, impact, social impact, impact measurement. 